\title{
The Role of The Village Government in the Economic Development of Fisherman Communities in Pulau Harapan Village
}

\author{
Hasdinawati $^{1}$ Ernawati $^{2}$ Abd Wahid ${ }^{3}$ \\ ${ }^{1,2,3}$ STISIP Muhammadiyah Sinjai \\ Email: hasdinawati02@gmail.com
}

\begin{abstract}
Pulau Harapan Village is one of the villages in the Pulau Sembilan District area. most of the population work as fishermen. This study aims to determine the role of the village government in the economic development of fishermen communities in Pulau Harapan Village, Pulau Sembilan subdistrict. The research method used is descriptive qualitative research. Data collection is observation, interviews with resource persons, namely the Head of the Harapan Island Village, the Secretary of the Pulau Harapan Village, the Tohoh community, and the Harapan Island Fisherman Community. Meanwhile, data analysis includes: collecting data, reducing data, assessing data (grouping primary and secondary data), and interpreting data, which is done by critically analyzing the collected data and finally arriving at a conclusion. The results of the study conclude that the Village Government in the Economic Development of the Fishermen Community in Pulau Harapan Village, Pulau Sembilan Subdistrict has not played a sufficient role, especially in realizing and developing production centers, processing industry centers, access to village transportation, building community agribusiness, building business facilities/business centers in rural areas as well as in developing the information and communication technology community.
\end{abstract}

Keywords: Role,village government, fisherman, economic development

\section{INTRODUCTION}

The gap between regions is a policy issue that has long been a concern of the government (Akib, 2009; Langkai et al., 2016; Pülzl \& Treib, 2017; Saggaf, 2015; Sulanjari, 2020). Even though the level of inequality between regions is getting better, the government still needs to increase policy interventions to continue to reduce the level of inequality between regions (Cooke et al., 2016; Dennig et al., 2015; Ha \& Kim, 2016; Hassine, 2015) through the implementation of policies to accelerate the development of frontier, outermost areas. One of them is the policy of the Regulation of the Minister of Villages, Development of Disadvantaged Areas, and Transmigration of the Republic of Indonesia Number 15 of 2015 concerning the Strategic Plan of the Ministry of Villages, Development of Disadvantaged Areas, and Transmigration for 2015-2019, states that the development and development of transmigration areas is one of the instruments to encourage village development through the fulfillment of minimum service standards, especially in villages and rural areas in underdeveloped and border areas, outer islands, islands, and coastal areas as well as the development of linkages between villages and cities in areas that are prepared as New Urban Areas.

The island area in Sinjai Regency which is known as Pulau Sembilan is famous for its richness and diversity of natural resources, both recoverable and non-recoverable. Natural 
resources and human resources that are reliable and supported by science and technology that are supported by policies on proper utilization and management can be great assets for national development. The opportunities they have are the wealth of natural resources and potential human resources to be developed for their utilization. The natural resources of Pulau Sembilan have important implications for fishery activities, environmental conservation, marine tourism, and other related environmental service activities. Pulau Harapan Village is one of the areas located between the rows of islands in the Pulau Sembilan District, Sinjai Regency, with an area of $1.75 \mathrm{~km}^{2}$. Pulau Sembilan Subdistrict, which has a coastline of $20 \mathrm{~km}$, is estimated to have quite a lot of marine cultivation development potential. Almost all of the people in Pulau Harapan Village are fishermen or reach 1,604 out of a total population of 3,432 people. Most of the fishing community, especially fishermen laborers, still have a low level of welfare because their income is uncertain every day and only depends on their livelihoods on marine products, causing them to be classified as poor.

The role of the village government is highly expected in developing fishing communities so that marine resources as a regional potential can be utilized and managed properly (Daan et al., 2005; Mascia et al., 2010; Sumaila et al., 2000; Ward \& Myers, 2005), because so far the government has not played a role in community economic development (Alder \& Sumaila, 2004; Allison et al., 2012; Burke et al., 2002; Sethi et al., 2010). Some of the fishing communities of Harapan Island have not been able to manage marine resources as their regional potential. Many factors cause this, such as the strategies used in managing marine potential in the form of assets, access, and activities carried out by fishermen. Another condition that contributes to worsening the level of fishermen's welfare is the habit or lifestyle, the obstacle is the consumptive lifestyle, where when the income is high, it is not saved for preparation for famine (an increasing season of lack of fish), but is used as an opportunity to buy secondary needs. Therefore, Pulau Harapan Village is important to be researched to find out the causes of the problems in the research area, namely Pulau Harapan Village and to see the conditions that occur between the assets, access, and activities of the fishing community.

\section{METHOD}

While the type of research is a qualitative descriptive study. Moleong (Arhas \& Suprianto, 2020) describes that qualitative methods are research that intends to understand the phenomena experienced by research subjects such as behavior, perceptions, motivation, actions, and others. The data source uses primary data, namely, data obtained after conducting a series of interviews and seeing directly with informants and secondary data, namely supporting data obtained from literature and articles related to the issues discussed the Government's Role in Community Economic Development Fisherman This research will be conducted in Pulau Sembilan District, namely Pulau Harapan Village. In a 1 (one) year research period with informants, namely the Village Head, Village Secretary, Village Owned Enterprises Management and the Community using Data Collection Techniques (Rahmat, 2009), namely Observation, interview, and documentation. This interactive analysis technique is data reduction, presentation of data, and concludes. 


\section{RESULT AND DISCUSSION}

As a system, fishing communities consist of social categories that form social unity. The fishing community also has a value system and cultural symbols as a reference to people's daily behavior. Cultural factors in fishing communities differentiate fishing communities from other social groups. Most of the coastal communities, either directly or indirectly, depending on their potential for life by processing fishery resources.

\section{Creating and developing production centers, processing industrial centers}

In the development of the community's economy, through the realization and development of production centers or processing industrial centers, it has not been realized. From the results of research related to production centers and processing industry centers in Pulau Harapan Village, realizing and developing production centers has not been carried out because they are constrained by the location of the island where the area of Harapan Island is only $1.75 \mathrm{Km}^{2}$ and the rest is the ocean, so it needs careful planning, Meanwhile, for the development of human resources for fishing communities in the planning stage and the future there may be planning, but it needs careful consideration because the conditions of the village, especially the island of hope, must have a sustainable review.

Meanwhile, people currently need fish auction on Kambuno Island or Harapan Island. Based on the results of observations, it is known that fishermen in selling their crops are brought to the Lappa Fish Pelelengan Place Lappa Village, North Sinjai District with several price variations of catch fish, this is by the fish price data.

\section{Table 1.}

Fish Prices at the Lappa Fish Auction Place

\begin{tabular}{|c|c|c|}
\hline Number & $\begin{array}{l}\text { Type of Fish } \\
\end{array}$ & Price/kg \\
\hline 1. & Mackerel Fish & Rp. 45.000 \\
\hline 2. & Sunu Fish & Rp. 70.000 \\
\hline 3. & Grouper Fish & Rp. 15.000 \\
\hline 4. & Selur Fish & Rp. 10.000 \\
\hline 5. & Anchovy & Rp. 5.000 \\
\hline 6. & Squid & Rp. 27.000 \\
\hline 7. & Octopus & Rp. 45.000 \\
\hline 8. & Cuttle Fish & Rp. 30.000 \\
\hline
\end{tabular}

Source: Results of Primary Data Processing, 2020

\section{Improve Village Transportation Access}

In the economic development of the community, through the realization and development of a production center or processing industry center, this was expressed by the Head of Pulau Harapan Village, that the Government must prepare a transport ship on Liang- 
Liang Island to facilitate access for school children and the community for each. the requirements needed are for example the management at the Village Office, while in the future for the provision of inter-island transportation while the planning stage is to facilitate access to education and community needs. However, until now, people still use private property and rent for transportation purposes. This shows that the efforts of the village government in increasing access to village transportation have not been realized, because the boats that have been up to now are owned by the community which, if used, must use a fee.

Based on the observation, it is known that Pulau Harapan Village has communityowned transportation facilities with the following transportation costs:

Table 2.

Types of Transportation Facilities and Costs of the Spreader

\begin{tabular}{ccc}
\hline Number & Type Of Boat & Cost \\
\hline 1. & Ordinary Passenger Ship & Rp. 15.000/one-way Source \\
2. & Ship Speed Boat & Rp. 30.000/one-way Source \\
\hline
\end{tabular}

Source: Harapan Island Village Government, 2020

\section{Developing Inter-Village Cooperation}

In developing the community's economy through the development of cooperation between villages in Harapan Island, Pulau Sembilan Subdistrict, it is realized by providing Village-Owned Enterprises (Village Owned Enterprises) that were formed in 2016 to help develop the community's economy, this shows that the Village-Owned Enterprises (Village Owned Enterprises) of Pulau Harapan has formed for the economic development of the people of Pulau Harapan Village. In the economic development of the community, the village government has formed Village Owned Enterprises, with a total of funds managed by twentyfive million Rupiahs and the Village Government has played a role in developing the community's economy through the formation of village-owned enterprises, in which the funds are lent to residents who need funds or venture capital.

Based on the results of observations, it is known that in Pulau Harapan Village there are Village-Owned Enterprises, with a management structure as follows:

Table 3.

Village Owned Enterprises Management for Pulau Harapan Village

\begin{tabular}{clc}
\hline Number & \multicolumn{1}{c}{ Name } & Position \\
\hline 1. & Syamsul Habibi, S.Sos. & Chairman \\
2. & Hardianti, S.Pd. & Sekretaris \\
3. & Kurnia Darwis & Treasure \\
\hline
\end{tabular}

Source: Harapan Island Village Government, 2020 


\section{Building community agribusiness}

Pulau Harapan Village community economic development through community agribusiness development is still in the planning stage the reason that the village government is focused on infrastructure development, but in the future, it will plan to build community agribusiness to increase fishing community access to capital and marketing. With the focus on the development of government infrastructure by taking into account the condition of the population, such as the construction of fish farming facilities and infrastructure, construction of clothesline floors for the catch of fishermen, repair of docks and traffic, etc., infrastructure development includes the following:

\section{Table 4.}

Pulau Harapan Village Infrastructure Development

\begin{tabular}{lll}
\hline Number & \multicolumn{1}{c}{ Form Activity } & \multicolumn{1}{c}{ Total } \\
\hline 1. & Water Transport Ship & 2 Units \\
2. & Village Road & $3.000 \mathrm{~m}$ \\
3. & Drainage & $1000 \mathrm{~m}$ \\
4. & Construction of Boat Back Facilities & 1 Package \\
5. & Construction of 1 Package Concrete Pier & 1 Package \\
6. & Construction of facilities and infrastructure for 1 & 1 Unit \\
7. & Unit fish farming & 30 units \\
\hline
\end{tabular}

Source: Harapan Island Village Government, 2020

\section{Build business facilities/business centers in rural areas}

In developing the community's economy through the construction of business facilities/business centers in Pulau Harapan Village, it is still in the planning stage which is carried out in stages because the Sembilan island government focuses on planning the fish farming business facilities and infrastructure. However, this does not reduce the community's intention to build their own business at their respective homes. Based on observations it is known that in Pulau Harapan Village there is no business facility or business center, most of which only have public markets and a few trading stalls.

\section{Table 5.}

Harapan Island Village Trading Business Facility

\begin{tabular}{clc}
\hline Number & \multicolumn{1}{c}{ Facility } & Total \\
\hline 1. & General Market & 1 Unit \\
2. & Mixed Goods Kiosk & 172 Unit \\
3. & Clothes Kiosk & 2 Unit \\
4. & of food stalls & 11 Unit \\
\hline
\end{tabular}

Source: Harapan Island Village Government, 2020 
32 |Jurnal Administrare: Jurnal Pemikiran Ilmiah dan Pendidikan Administrasi Perkantoran

Volume 8 Issue 1, January-June 2021. Pages 27-36

\section{Developing Community, Information, and Communication}

The development of the community's economy through the development of the information and communication technology community has not materialized in Pulau Harapan Village, the development of information. Internet Network. To get Internet access, people have to do it themselves. However, from a community perspective, Pulau Harapan Village already has a Fisherman Group Community. given the name Coastal Sea Group, this is by the data the author obtained, where the composition of the management is as follows:

Table 6.

Management of the Pulau Harapan Village Sea

\begin{tabular}{cllc}
\hline No & & \multicolumn{1}{c}{ Management } & Coast \\
\hline 1. & Chairman & Saeful & Rp. 10.000 .000 \\
2. & Secretary & Mustamin & Rp. 5.000 .000 \\
3. & Treasure & Arsa & Rp. 4.000 .000 \\
4. & Members & Haeruddin, Sapril, Saefuddin, Iman & Rp. 3.000 .000 \\
\hline
\end{tabular}

Source: Ocean Coast Group, 2020

From the results of the research, it can be concluded that the village government has not played a role in the development of the information and communication technology community, but the village government continues to strive and plan so that all aspects related to community economic development can be fulfilled, but even so, the people of Harapan Island village are creative because they have been able to make efforts. in increasing their economy by forming fishermen groups.

\section{Discussion}

\section{Creating and developing production centers, processing industrial centers}

Realizing and developing production centers, processing industrial centers, namely creating their production centers and fishery product processing centers (Negara, 2014). that the economic development of the community through the realization and development of own production centers or fisheries processing industrial centers has not been realized because it is constrained by inadequate locations, because the area is narrow, only $1.75 \mathrm{~km} 2$ which is inhabited by 1,769 inhabitants or 922 family heads and the rest is the ocean, so it needs careful planning to play a role in realizing a production center for the residents of Harapan Island who mostly work as fishermen, so in essence that in realizing and developing production centers and industrial centers, temporary management is in the planning stage, especially the resources of the village fishing community Hope Island.

\section{Improve Village Transportation Access}

Increasing access to village transportation is to improve rural transportation facilities so that they can connect with economic growth centers between villages and between cities (Christiawan \& Budiarta, 2017). that the economic development of the community through 
increased transportation has not been realized by the village government, the only transport ships provided by the Village Government are transport ships on Liang-Liang Island as access for school children and the community for every need needed when taking care of something at the Village Office. Meanwhile, in the case of dispersers, it is still in the planning stage, which will provide inter-island transportation ships so that later the fishing community can easily market the results they get from fishing.

\section{Developing Inter-Village Cooperation}

Each region has its potential and limitations. The limitations of local governments in carrying out development and providing public services that reach all communities have the potential to cause unequal distribution of development results and public services. (Maria AP Sari, 1969) In this case, developing cooperation between villages is to establish cooperation with other regions and between government and private including cooperation in the management of Village Owned Enterprises, (through the establishment of Joint Village Owned Enterprises or cooperation between. Village Owned Enterprises as an instrument of social capital which is expected to be a bridge that connects the village with the economic sphere outside it so that it becomes an economic amplifier in the countryside. To achieve this condition requires strategic steps. and tactical to integrate the potential, market needs, and the formulation of the institution's design into a plan. Also, it is necessary to pay attention to localization potential and policy support (goodwill) from the government above it to eliminate the low surplus in rural economic activity due to the possibility that the economic sector will not develop in rural areas (President of the Republic of Indonesia, 2014).

That the Village Government has played a role in community economic development through the development of cooperation between villages such as the establishment of VillageOwned Enterprises so that there is a cooperation between Village Owned Enterprises and the community in terms of assistance or capital loans, however, the establishment of a business entity must be accompanied by efforts to strengthen capacity and supported by regional (district/city) policies that facilitate and protect this business from the threat of competition from big investors. Given that this business entity is a new economic institution operating in rural areas and still needs a strong foundation to grow and develop. The foundation builder for the establishment of Village Owned Enterprises is the Government. In its operationalization, Village Owned Enterprises should ideally be supported by a village monetary institution (financing unit) as a unit that conducts financial transactions in the form of credit and savings. If the economic institutions are strong and supported by adequate policies, then economic growth accompanied by equitable distribution of assets to the people at large will be able to overcome various economic problems in rural areas.

\section{Building community agribusiness}

Community agribusiness, agribusiness is a concept that is integrated. Agribusiness is an economic activity that produces a benefit from these activities in the world of agriculture, covering all activities from the procurement of raw materials, the cultivation process, the marketing process, the trading of agricultural products to the hands of consumers. Agribusiness, when viewed from an economic perspective, these activities should be able to generate benefits for the perpetrators, either directly or indirectly (Agustar \& Febriamansyah, 2008). and Cooperatives. 
the Village Government has not played a role in community economic development through community agribusiness development, this is evident in the absence of a fish market or fish auction because currently, the village government focuses on infrastructure development, but to empower the economy, the Pulau Harapan Village Government has strived for several things in the field of fisheries. Development of fish farming business facilities and infrastructure, construction of clothesline floors for fishermen's catch, repair of concrete piers, and construction of boat rest facilities, all of which lead to the economic development of fishing communities. This of course should be the main focus for the future government.

\section{Build business facilities/business centers in rural areas}

Development of business facilities in the village needs to be developed so that it has a big influence on how much it contributes to driving the economy. With the abundance of marine products by the fishermen community in Pulau Harapan Village, special fisheries business facilities are needed. the village government has not played a role in building business facilities or business centers, which is known if there is no fish trading place in Harapan Island Village so that most of the fishermen's catch is traded at the Lappa Fish Auction Place (TPI). located in the City Center, which is about 1 hour by boat to get to that location, however, the Village Government continues to make efforts to improve the community's economy through planning the development of fish farming business facilities and infrastructure as a business facility in Pulau Harapan Village.

\section{Developing Community, Information, and Communication}

A technology Information system is a combination of information technology and people activities. Even the most sophisticated information technology, but no one operates it results in the information system not running optimally. The combination of information technology and human management is the key to the successful application of information systems. Repetitive jobs can be replaced by a system to simplify work. The progress of the role of information systems causes organizational performance to become more efficient and effective. According to Law number 6 of 2014 concerning Villages, Village Development is an effort to improve the quality of life and life for the maximum welfare of the village community. Furthermore, the Law also explains that, in this case, village development includes four fields of development, namely the implementation of village governance, implementation of village development, village community development, and empowerment of village communities. Village development which is focused on the four spheres of development aims to emphasize the essence of the village law, namely to give greater authority to villages to not only become objects of development but to become more independent objects as well as development subjects. Such village development can be supported by an information system and the concept of eGovernment is a major consideration for public sector organizations (village governments) that carry out information system planning to provide important input and facilitate the process of planning and monitoring and evaluating development results (President of the Republic of Indonesia, 2014 ).

The fishermen group in Pulau Harapan Village not only focuses on fishing activities but also organizes family arisan activities which are carried out regularly. The programs carried out by this fishermen group are the initiative of the group members who feel they are responsible for the welfare of their fellowmen. The role of fishermen groups in Pulau Harapan Village is not 
only as a fishing group but also plays a role in various fields of life for the fishing community, although only at the group level. The fields of the fishermen's group's role include the economic sector, the socio-religious sector, the political security sector, and the technical education sector.

\section{CONCLUSION}

The results of the study conclude that the Village Government in the Economic Development of the Fishermen Community in Pulau Harapan Village, Pulau Sembilan Subdistrict has not played a sufficient role, especially in realizing and developing production centers, processing industry centers, access to village transportation, building community agribusiness, building business facilities/business centers in rural areas., as well as in developing the information and communication technology community. The development of processing centers has not yet been achieved because it is constrained by the village's narrow area. Likewise, the increase in transportation has not materialized, because there is no public transportation vessel provided by the Village Government, but this is still in the planning stage. Likewise, the role of the Village Government through community agribusiness development has not yet been realized because there is no fish market or the fish auction. Likewise, the role in building business facilities has not yet been realized, but the Village Government continues to make efforts to improve the economy through planning the development of fish farming business facilities and infrastructure. Likewise, the role in the development of the information and communication technology community has not yet been realized, but the village government continues to make efforts to plan so that all aspects related to community economic development can be fulfilled. Meanwhile, the role of the Village Government through the development of cooperation between villages has been carried out, such as with the formation of Village-Owned Enterprises so that there is a cooperation between Village Owned Enterprises and the community in terms of assistance or capital loans.

\section{REFERENCES}

Akib, H. (2009). Artikulasi Perkembangan Ilmu Administrasi Publik. Jurnal Baca Edisi, 2(3).

Aksan, H.Rekson, Limba, S., \& Tanzil. (2018). Peran Kepala Desa Dalam Meningkatkan Pembangunan Desa (Studi di Desa Baliara Selatan, Kabupaten Bombana) Oleh: Neo Societal, 3(1), 244-253.

Alder, J., \& Sumaila, U. R. (2004). Western Africa: A fish basket of Europe past and present. Journal of Environment and Development. https://doi.org/10.1177/1070496504266092

Allison, E. H., Ratner, B. D., Åsgård, B., Willmann, R., Pomeroy, R., \& Kurien, J. (2012). Rights-based fisheries governance: From fishing rights to human rights. Fish and Fisheries. https://doi.org/10.1111/j.1467-2979.2011.00405.x

Ardinal Barlan, Z., \& M. Kolopaking, L. (2015). Peran Paguyuban Dalam Pembangunan Kawasan Desa. Sodality: Jurnal Sosiologi Pedesaan. https://doi.org/10.22500/sodality.v2i2.9419

Burke, L., Selig, E., \& Spalding, M. (2002). Reefs at Risk in Southeast Asia. In World Fishing.

Cooke, E., Hague, S., \& McKay, A. (2016). The Ghana Poverty and Inequality Report - 2016. Unicef.

Daan, N., Gislason, H., Pope, J. G., \& Rice, J. C. (2005). Changes in the North Sea fish 
36 Jurnal Administrare: Jurnal Pemikiran Ilmiah dan Pendidikan Administrasi Perkantoran
Volume 8 Issue 1, January-June 2021. Pages 27-36

community: Evidence of indirect effects of fishing? ICES Journal of Marine Science. https://doi.org/10.1016/j.icesjms.2004.08.020

Dennig, F., Budolfson, M. B., Fleurbaey, M., Siebert, A., \& Socolow, R. H. (2015). Inequality, climate impacts on the future poor, and carbon prices. Proceedings of the National Academy of Sciences of the United States of America. https://doi.org/10.1073/pnas.1513967112

Ha, E., \& Kim, J. H. (2016). Global inequality. In Encounters with World Affairs: An Introduction to International Relations. https://doi.org/10.4324/9781315169446-12

Hassine, N. B. (2015). Economic Inequality in the Arab Region. World Development. https://doi.org/10.1016/j.worlddev.2014.09.011

Hermansyah. (2015). Peran Kepala Desa Dalam Pelaksanaan Pembangunan Kecamatan Tana Lia Kabupaten Tidung. Pemerintahan Integratif, 3(2), 351-362.

Langkai, J. E., Akib, H., Musah, C. I., \& Naharia, O. (2016). The Impact of the Implementation Based on the Policy Development Neighborhood for the Social Welfare in the City Of Manado. Mediterranean Journal of Social Sciences, 7(2 S1), 259.

Mascia, M. B., Claus, C. A., \& Naidoo, R. (2010). Impacts of marine protected areas on fishing communities. Conservation Biology. https://doi.org/10.1111/j.1523-1739.2010.01523.x

Pülzl, H., \& Treib, O. (2017). Implementing public policy. In Handbook of Public Policy Analysis: Theory, Politics, and Methods. https://doi.org/10.4324/9781315093192-14

Saggaf, H. M. (2015). Dampak Kebijakan Pengembangan Wilayah Berbasis Potensial Lokal Terhadap Pergeseran Struktur Ekonomi Kabupaten Bantaeng. Universitas Negeri Makassar.

Sethi, S. A., Branch, T. A., \& Watson, R. (2010). Global fishery development patterns are driven by profit but not trophic level. Proceedings of the National Academy of Sciences of the United States of America. https://doi.org/10.1073/pnas.1003236107

Sugiman. (2018). Pemerintahan Desa. Binamulia Hukum, 7(1), 82-95. https://doi.org/10.37893/jbh.v7i1.16

Sugiyono. (2017). Pendekatan Kuantitatif, Kualitatif, Kombinasi, $R \& D$ dan Penelitian Evaluasi. Alfa Beta.

Sulanjari, D. Y. (2020). E-Government Implementation in the Education Zone Service in Makassar City. Jurnal Ad'ministrare, 6(2), 153-158.

Sumaila, U. R., Guénette, S., Alder, J., \& Chuenpagdee, R. (2000). Addressing ecosystem effects of fishing using marine protected areas. ICES Journal of Marine Science. https://doi.org/10.1006/jmsc.2000.0732

Ward, P., \& Myers, R. A. (2005). Shifts in open-ocean fish communities coinciding with the commencement of commercial fishing. Ecology. https://doi.org/10.1890/03-0746 